\title{
Evaluation of the role and usefulness of clinical pharmacists at the Fangcang hospitals during COVID-19 outbreak
}

\author{
Dongyuan Wang ${ }^{1}$, Yihui Liu ${ }^{1}$, Fang Zeng ${ }^{1}$, Fang Cheng ${ }^{1}$, Chen $\mathrm{Shi}^{1}$, Yong Han ${ }^{1}$, and Yu \\ Zhang $^{2}$
}

${ }^{1}$ Huazhong University of Science and Technology Tongji Medical College

${ }^{2}$ Affiliation not available

April 28, 2020

\begin{abstract}
Background: Fangcang hospital (cabin hospitals) played a key role in isolation and control of the infection sources during COVID-19 epidemic. The patients at Fangcang hospitals were complicated, and many had different symptoms of COVID-19, some had comorbidities or mental stress, and many were confused with the drug usages etc. Objective: Due to the limitation and high work pressure of first line medical workers, patients' various problems couldn't be explained well. Under this circumstance, online pharmaceutical care was provided by clinical pharmacists. This study was a retrospective study to evaluate the role and usefulness of clinical pharmacists at Jianghan Fangcang Hospital. Besides, this new mode of service was also introduced in detail to provide options for pharmacists in other hospitals. Methods: The pharmaceutical care included medication education via broadcast station, and medication reconciliation, optimization of drug use, monitor of adverse drug events, and psychological comfort via WeChat $\mathbb{R}$ one-to-one service. In this study, we analyzed patients' characteristics and drug usages, concluded almost 200 patients' problems classified into 6 aspects solved by clinical pharmacists, and also assessed the patients' satisfaction with our service. Results: The clinical pharmacist help patients solved almost 200 questions, which mainly focused on the drug related problems including drug usage (65.38\%), medication reconciliation (55.13\%), drug precautions (23.1\%), adverse drug reactions $(35.9 \%)$, and psychological counseling (32.05\%). Through 35 days' services, Most patients were satisfied with clinical pharmacist service(66.7\% great, $18.0 \%$ good). Besides, most patients thought the service had positive effect on their mental stress(16.7\%great, $43.6 \%$ good, $26.9 \%$ fair). Conclusion: The results of the retrospective study indicated that clinical pharmacist can effectively reduce and prevent drug-related, life-related and COVID-19-related problems for COVID-19 patients. This work may provide possible work patterns for clinical pharmacist in other hospital and give more professional service for Fangcang hospital patients.
\end{abstract}

\section{Introduction}

Since a novel coronavirus has caused worldwide outbreak of COVID-19. The spectrum of COVID-19 ranges from mild to severe and even death ${ }^{1-4}$. Up to now, more than $80 \%$ of the confirmed cases of COVID-19 are mild or common illness. Currently there are no specific antiviral treatment for COVID-19 ${ }^{5-7}$. The World Health Organization (WHO) has now declared the coronavirus a global pandemic.

Since the SARS-CoV-2 is highly infectious, in order to control the spread of the epidemic, Fangcang hospitals were established as a new major public health facility, which had large space, multiple beds and possessed multiple functions, including emergency treatment, clinical examination and centralized management ${ }^{8-10}$. Until Feb. $24^{\text {th }}, 2020$, there have been 16 Fangcang hospitals established for more than 12,000 patients with mild and common COVID-19 in China. As a requisite functional module of the Fangcang hospital, the Fangcang pharmacy and clinical pharmacists also played an important role in ensuring the supply and safety of therapeutic drugs for the COVID-19 patients $^{9}$. 
As the largest Fangcang hospital, Jianghan Fangcang Hospital was the first one to open up for mild/ moderate COVID-19 patients, which provided about 1500 beds. Most of the patients had no obvious clinical symptoms or had mild symptoms after they were hospitalized. Common respiratory symptoms include fever, dry cough, and shortness of breath. A few patients were accompanied with nasal obstruction, running nose, pharyngalgia, myalgia and diarrhea. The therapeutic regimen was simple and mainly included antiviral and symptomatic treatment. However, the large number and complicated sources of patients with mental stress and comorbidities, make the treatment more complicated and difficult. There were also many special patients, such as child, pregnant and senile ones resulting in a great difficulty of treatment assignment.

The standard treatment for patients in the Fangcang hospitals included, as necessary, antiviral agents, traditional Chinese medicines, immunomodulator, glucocorticoid, intestinal microecological modulators etc. And other medicines for chronic diseases. Under this circumstance, there are many drug related problems such as drug interventions, drug interactions and adverse drug reactions, which lead to high risks of drug safety in COVID-19 patients, especially for those special patients. Therefore, it's important to carry out monitoring of drug therapeutic effect and adverse reactions, for timely guiding medical workers and patients to use drugs rationally, provide relevant drug consultation.

This study was a retrospective study on the benefit of pharmaceutical care for patients in Jianghan Fangcang Hospital. Data were collected from medical records, patient questionnaire and WeChat ${ }^{\circledR}$ online service records. After 35 days' pharmaceutical care, clinical pharmacist help 349 patients solved about 196 different questions concluded in this paper. The satisfaction with patients was assessed through discharged patients' questionnaire.

\section{Methods}

\section{Ethics statement}

This study protocol was approved by the Institutional Review Board of Union Hospital, Tongji Medical College of Huazhong University of Science and Technology (IRB Number: 104). Since this study was merely a retrospective review of the routine service that was put in place and data were gathered from existing documents based on routine work. Personal information was protected in the aggregated data.

\section{Patients}

A retro-prospective study was performed on the patients who were diagnosed of COVID-19 and received pharmaceutical care services at the Jianghan Fangcang Hospital, from February $5^{\text {th }}, 2020$ to March $10^{\text {th }}$, 2020. Patients who refused to fill in questionnaires and receive pharmaceutical care were not included in this study. The sample size was determined to be 349 patients.

\section{Pharmaceutical care service}

Besides the supplement of therapeutic drugs, clinical pharmacists also played important role for serving pharmaceutical care. Clinical pharmacist team explored the online pharmaceutical care service mode according to the special condition of the Fangcang hospitals, and provided remote pharmaceutical care services to patients, online pharmaceutical consultation and non-contact services mainly implement through WeChat ${ }^{\circledR}$ , so as to ensure one-on-one communication with the patients and solve their medication problems timely and effectively. Our pharmaceutical care plan including:

(1) A series of "Rational Drug Use" science broadcasting programs were opened to introduce the common medical knowledge to patients, including medical instructions, drug usage, drug interactions and adverse drug reactions. The programs cover various aspects of treatment, including antiviral agents, antibacterial agents, traditional Chinese medicines, nutritious diet, post-discharge management, emotional regulation, etc.

(2)The WeChat ${ }^{(\mathrm{r})}$ ID of "clinical pharmacist in the Fangcang hospital" was established and actively publicized, so that patients in need of help could voluntarily contact clinical pharmacists by WeChat ${ }^{(\mathrm{r})}$, and fill in the "self-reported questionnaire". Thus, the basic information about initial symptoms of COVID-19, basic comorbidities and their medication could be obtained by online consultation. 
(3)Joined COVID-19 patients were required to acquire the first pharmaceutical care and follow-up visit within $24 \mathrm{~h}$ of the next day, ensuring that all patients could timely obtain service.

(4)Clinical pharmacists were assigned to patients according to their disease conditions. WeChat ${ }^{(\mathrm{r})}$ is used to provide 24-hour online "one-to-one" pharmaceutical care, including providing indications, dosage, adverse drug reactions.

(5)Patients received follow-up visit after discharge to monitor their physical condition.

The inpatients' questionnaire survey items

Each item was independently created by the clinical pharmacists taking into consideration of usual pharmaceutical care. The survey included patient basic information, initial symptoms of COVID-19, patient's mental state, comorbidities, the medications including antivirals, antibiotics and other drugs, adverse drug reactions and so on. The questionnaire was administered to the patients before they received clinical pharmacist on-line service. Patients refused to service were excluded from this study.

Usefulness of the online pharmaceutical care service

Between February $5^{\text {th }}$ and March $10^{\text {th }} 2020$, the discharged patients' questionnaire was administered to 78 patients who received pharmaceutical care service at the Jianghan Fangcang Hospital. The survey included the days for antiviral and antibiotic therapy, the usefulness of pharmacist care service on patients' rational medication and mental situations, the satisfaction with clinical pharmacist service. Patients who did not received pharmacist service were excluded.

\section{Results}

\section{Demographic}

1848 patients were hospitalised in Jianghan Fangcang Hospital and 349 patients were willing to add us on WeChat ${ }^{(\mathrm{r})}$ to receive the pharmaceutical care. Before we performed our service, the patients were allowed to fill in the inpatients' questionnaire. A total of 349 patients at Fangcang hospital were admitted to this study with an average age of $45.5+-10.6$ years and $57.6 \%$ female. All these patients were diagnosed with mild COVID-19, who had fever(79.7\%), cough(60.5\%) with $43.6 \%$ sputum, pharyngalgia, myalgia, headache(57.3\%), shortness of breath $(42.7 \%)$, chest distress $(38.4 \%)$, diarrhea $(35.8 \%)$, nausea and vomiting $(24.9 \%)$, dyspnea $(24.4 \%)$, eye symptoms $(18.3 \%)$, sneeze(17.2\%), rhinobyon (14.0\%). Clinical pharmacist need to be more careful with the patients who had more infection symptoms and anxiety in case they got worse. At Fangcang hospital, the patients' conditions were complicated and many had comorbidities such as hypertension(12.9\%), hyperlipidemia (9.2\%), thyroid disease $(8.9 \%)$, diabetes $(7.2 \%)$, heart disease $(3.4 \%)$, nephropathy(1.7\%), cancer(1.1\%) and other diseases(12.6\%). Details of patient's characteristics are summarized in Table1. The complicated patient conditions indicated an urgent need for pharmaceutical care at Fangcang hospital.

Psychological effects of the COVID-19 outbreak

Patients are usually significantly stressed by the big public health emergencies such as SARS ${ }^{11}$. The patients with COVID-19 could suffer from severe psychological burden during COVID-19 outbreak. Before we initiated our pharmaceutical care for patients, we had a preliminary understanding of the patient's psychological status. Our study showed that a few people' spirits were bad $(4.6 \%, 16 / 349)$ and $32.09 \%(120 / 349)$ were low. Many patients had low sleep quality(44.12\%), and a few (17.91\%) had really bad sleep. Most common reported influence factors included anxiety and fear of epidemic situation and clinical outcomes of medications. We performed drug education and psychological comfort for patients with bad spirit and enhanced the visit frequency for them. From the questionnaire for discharged patients(n=78), we found our service had positive effect on their mental stress(16.7\%great, $43.6 \%$ good, $26.9 \%$ fair).

Medication and adverse drug reaction 
Patients at Fangcang hospital were treated with various antivirals, antibiotic, traditional Chinese medicine and other symptomatic treatment drugs shown in Table 2. The antivirals taken by patients included Arbidol(70.8\%), Oseltamivir(82.5\%), Chinese patent medicine of Lianhua Qingwen Granule(92.8\%), Chinese herbal decoction(64.8\%), Ribavirin(4.9\%), Interferon- $\alpha(1.7 \%)$. With the weakened immune system, few patients were companied with bacterial infection in pneumonia, thus antibiotics were taken. The antibiotics include moxifloxacin(73.1\%), cefdinir(36.7\%), levofloxacin(32.1\%), amoxicillin(6.3\%), azithromycin(3.2\%). Due to the concerns about outcome of medications and a lack of common medical knowledge, many patients took more than one antivirals or antibiotics with the same function overtime, which not only failed to achieve the therapeutic curative efficacy, but also caused a variety of adverse drug reactions. Besides, many patients also took various treatments for their comorbidities, and these drugs may have interactions with antivirals or antibiotics, which may lead great risk of drug use of COVID-19 patients.

Before the pharmaceutical care provided, many patients reported they had adverse drug reactions $(61.9 \%)$, including diarrhea $(27.5 \%)$, nausea $(27.2 \%)$, fatigue $(24.4 \%)$, insomnia $(16 \%)$, vomiting $(11.7 \%)$, itchy skin $(10.9 \%)$, constipation $(5.2 \%)$, difficulty urinating (4.6\%), and other adverse drug reactions(6.9\%), shown in Table 3. While patients may get confused with these reactions, as some adverse drug reactions were similar with the symptoms of the COVID-19. Thus, these reported adverse drug reactions need to be further confirmed by clinical pharmacists during patients' consultation.

Online pharmaceutical care service

In recent decades, clinical pharmacist have provided kinds of pharmaceutical care for patients with different diseases ${ }^{12-14}$. The remote pharmacy service such as telepharmacy have benefited numerous patients in settings the pharmacists are not available ${ }^{15-16}$. Due to the isolation of Fangcang hospital, and the special nature of COVID-19, a novel service model was developed by clinical pharmacists for the special circumstances of Fangcang hospitals. First, we gave "Rational Drug Use" science broadcasting programs, including the medical knowledge of antivirals, antibiotics, traditional Chinese medicine, diet of nutrition, precautious after discharge etc, which also make patients get familiar with clinical pharmacist. Second, patients were given "one-to-one" online pharmaceutical care service through WeChat ${ }^{\circledR}$. The patients were classified according to their medical conditions from the inpatients' questionnaire. The clinical pharmacists provided 24-hours online pharmaceutical care in case patients had drug related problems or negative emotions.

After 35 days' pharmaceutical care, we sifted and got 196 questions from patients which were classified into 5 aspects, including COVID-19 related problems(29.1\%), COVID-19 medication related problems(41.8\%), basic chronic illness related problem (12.2\%),life related problems at Fangcang hospital(7.7\%),matters of discharge (9.2\%), shown in Table 4 . These contents had been compiled into a book which be used as guidelines for patients at other Fangcang hospitals. From this survey we can see the demand for drug consultation by patients. The drug related problems included inappropriate combination of drugs, unclear indication for drugs, drug dosage, time of taking medicine, drug interaction problems and adverse drug reactions etc. Meanwhile, many patients concerned about the sources of infection, the way of transmission, the control of the epidemic situation, the disease recurrence, the possibility of mild patients to severe patients and whether they can be cured. The patients with basic chronic diseases faced the problems with poor disease control due to COVID-19. Most of the proposed advice or explanations were accepted by patients after service of clinical pharmacist.

\section{Satisfaction of pharmaceutical care service}

In order to evaluate the pharmaceutical care provided by clinical pharmacists, we designed a questionnaire for discharged patients, and 78 patients voluntarily completed the questionnaire. According to the survey results, shown in Table 5, 48.7\% patients communicate with the clinical pharmacist at least once a day, $28.2 \%$ patients communicate with the clinical pharmacist every 2-3 days. The pharmaceutical care service included drug usage (65.38\%), medication reconciliation (55.13\%), drug precautions $(23.1 \%)$, adverse drug reactions $(35.9 \%)$, and psychological counseling (32.05\%). We also found that $59.0 \%$ patients had insomnia, $42.3 \%$ patients were anxious, and $28.2 \%$ patients were afraid of disease, $20.5 \%$ depressed and $10.3 \%$ irritable. 
These results indicated that our clinical pharmacists did play an important role for pharmaceutical care in Fangcang Cabin hospitals.

Through 35 days' services, the recognition of clinical pharmacist was greatly improved, from $25.6 \%$ to $87.2 \%$, shown in Table 5. Most patients were satisfied with clinical pharmacist service(66.7\%great, $18.0 \%$ good), and they thought pharmaceutical care provided by clinical pharmacist was necessary for treatment and rehabilitation at Fangcang hospital(62.8\%great, $32.1 \%$ good). Besides, most patients thought the service had positive effect on their mental stress(16.7\% great, $43.6 \%$ good, $26.9 \%$ fair).

This study indicated that most patients need clinical pharmaceutical care services. The online pharmaceutical care service can not only help patients to use drugs rationally, but also relieve the patient's negative emotions and anxiety during the COVID-19 outbreak.

\section{Discussion}

Clinical Pharmacists are the guardians of safety medication of the patient's all the time. Due to the unique circumstances of Fangcang Hospital, clinical pharmacists were recommended to preform no-contact pharmaceutical care, which hindered the efficient and timely service for patients. The online pharmaceutical care service is often provided in places where clinical pharmacists unavailable ${ }^{15-16}$. A variety of technologies, models of care are used to develop and provide remote services, serving diversified populations with different pathological conditions ${ }^{[16]}$. However, the experiences on patients at Fangcang hospitals are rare. Recently, implementation of pharmaceutical care for patients at Jianghan Fangcang Hospital has been established during the COVID-19 outbreak. The goals of pharmaceutical care services were to improve medication safety and optimize clinical treatment outcomes and disease prognosis. This study was a retrospective research to analyze the clinical pharmacists' roles in the Fangcang hospital. This study showed that, many patients had various initiate symptoms, and some had chronic diseases or mental stress, making the treatment complicated and difficult. The drugs were also complicated including different kinds of antivirals, antibiotics and other agents, which often confused patients with the drug selection, drug dose, drug interaction and adverse reactions. Obviously, reduction in medication errors include drug interactions, adverse drug reactions following the suggestion of clinical pharmacists at Fangcang hospital has been shown to have a positive impact on COVID-19 patients. Therefore, it is particularly important to provide pharmaceutical care for patients to ensure safe and rational use of drugs.

From data of the questionnaire for 78 discharged patients, we found many patients(48.7\%) contacted clinical pharmacists frequently at least once a day, and only a few patients (14.0\%) contacted clinical pharmacist once a week( the lowest frequency), which indicated that our clinical pharmacists are in need for patients at Fangcang hospital. Through continuous instruction of pharmacist inpatient service, patients' concerns about medication can be alleviated. The clinical pharmacist help patients solved almost 200 questions, which mainly focused on the drug related problems including drug usage (65.38\%), medication reconciliation (55.13\%), drug precautions (23.1\%), adverse drug reactions (35.9\%), and psychological counseling (32.05\%). We also found that $59.0 \%$ patients had insomnia, $42.3 \%$ patients were anxious, and $28.2 \%$ patients were afraid, 20.5\% depressed and 10.3\%irritable when they stayed at Fangcang hospital.

Our study also revealed that, through continued guidance, many patients gained a better understanding of the drug indications, drug interaction and adverse reactions. Moreover, like previous studies report on the introduction of clinical pharmacists services with a high satisfactory $(>80 \%)$ and acceptance rate, most of patients in Fangcang hospital were satisfied with clinical pharmaceutical care and thought service was necessary and helpful during their COVID-19 treatment ${ }^{8-10}$. Besides, the patients' recognition of the pharmacist has greatly improved. All these data indicated that our online mode of novel pharmaceutical care service for patients at Fangcang hospital was safe, effective, and acceptable to COVID-19 patients. Some advices are also provided herein:(1)Online pharmaceutical care service mode should be established not only to COVID-19 patients but also to the general population as necessary; (2)Taken on heavy responsibility of drug safety guardians, pharmaceutical servicer and drug supplier, the clinical pharmacists in preventing the spread of COVID-19 should be strengthened. 


\section{Conclusion}

We performed pharmaceutical care for patients with mild or moderate COVID-19 at Jianghan Fangcang hospital. A retrospective study was followed to evaluate the usefulness of Clinical pharmacists at Fangcang hospitals, which indicate that clinical pharmacist can effectively reduce and prevent drug-related, life-related and COVID-19-related problems for COVID-19 patients. This work may reduce the work pressure of first line medical staffs, provide possible work patterns for clinical pharmacist in other hospital and give more professional service for Fangcang hospital patients.

Acknowledgements: The research reported in this publication was supported by National Key R\&D Program of China 2017YFC0909900. Yu Zhang and Yong Han contributed to the concept and design of this article, Dongyuan Wang and Yihui Liu helped for the data analysis and wrote this manuscript, Fang Zeng, Fang Cheng helped for the data collection. Chen Shi helped for the revision of the article.

\section{Reference}

1. Huang C, Wang Y, Li X, et al. Clinical features of patients infected with 2019 novel coronavirus in Wuhan, China. Lancet 2020;395:497-506.

2. Chen N, Zhou M, Dong X, et al. Epidemiological and clinical characteristics of 99 cases of 2019 novel coronavirus pneumonia in Wuhan, China: a descriptive study. Lancet 2020;395:507-513.

3. Wang $\mathrm{D}, \mathrm{Hu} \mathrm{B}, \mathrm{Hu} \mathrm{C}$, et al. Clinical characteristics of 138 hospitalized patients with 2019 novel coronavirus-infected pneumonia in Wuhan, China. JAMA. 2020 February 7 (Epub ahead of print).

4. Liu K, Fang YY, Deng Y, et al. Clinical characteristics of novel coronavirus cases in tertiary hospitals in Hubei Province. Chin Med J (Engl) 2020 February 7 (Epub ahead of print).

5. Cao B, Wang Y, Wen D, et al. A Trial of Lopinavir-Ritonavir in Adults Hospitalized with Severe Covid-19. N Engl J Med. 2020 March 18 (Epub ahead of print).

6. Li G, De Clercq E. Therapeutic options for the 2019 novel coronavirus (2019-nCoV). Nat Rev Drug Discov 2020;19(3):149-150.

7. Zhang J, Zhou L, Yang Y. Therapeutic and triage strategies for 2019 novel coronavirus disease in fever clinics. Lancet Respir Med 2020;8(3):e11-e12.

8. Yang Y, Zhu Y, Lian J, et al. Discussion on Pharmacy Management and Pharmaceutical Care Mode in Square Cabin Hospital [J/OL]. Herald of Medicine.2020:1-13.

9. Liu S, Luo P, Tang M, et al. Providing pharmacy services during the coronavirus pandemic. Int J Clin Pharm. 2020 Mar 28 (Epub ahead of print).

10. Chen S, Zhang Z, Yang J et al. Fangcang shelter hospitals: a novel concept for responding to public health emergencies. Lancet.2020 Apr.2(Epub ahead of print)

11. Maunder R, Hunter J, Vincent L et al. The immediate psychological and occupational impact of the 2003 SARS outbreak in a teaching hospital. CMAJ. 2003;168(10):1245-51.

12. Miller G, Franklin BD, Jacklin A. Including pharmacists on consultant-led ward rounds: a prospective non-randomised controlled trial. Clin Med. 2011; 11:312-6.

13. Nielsen TR, Andersen SE, Rasmussen M, Honore PH. Clinical pharmacist service in the acute ward. Int J Clin Pharm. 2013;35:1137-51.

14. Lombardi et al. Evaluation of the implementation of a clinical pharmacy service on an acute internal medicine ward in Italy. BMC Health Services Research.2018;18:259.

15. Omboni S, Tenti M. Telepharmacy for the management of cardiovascular patients in the community. Trends Cardiovasc Med. 2019;29(2):109-117. 
16. Niznik JD, He H, Kane-Gill SL. Impact of clinical pharmacist services delivered via telemedicine in the outpatient or ambulatory care setting: A systematic review. Res Social Adm Pharm. 2018;14(8):707-717.

Table 1. Demographics and clinical characteristics of patients

\begin{tabular}{ll}
\hline Characteristics & No. $(\%)$ of patients $\mathbf{( n = 3 4 9 )}$ \\
\hline Sex & \\
Female & $201(57.6 \%)$ \\
Male & $148(42.4 \%)$ \\
Age(years) & $45.5 \pm 10.6$ \\
Clinical symptoms with COVID-19 & \\
Fever (temperature [?]37.3 ${ }^{\circ}$ C) & $278(79.7 \%)$ \\
Cough & $211(60.5 \%)$ \\
Pharyngalgia, Myalgia, headache & $200(57.3 \%)$ \\
Shortness of breath & $149(42.7 \%)$ \\
Chest distress & $134(38.4 \%)$ \\
Diarrhea & $125(35.8 \%)$ \\
Nausea and vomiting & $87(24.9 \%)$ \\
Dyspnea & $85(24.4 \%)$ \\
Eye symptoms & $64(18.3 \%)$ \\
Sneeze & $60(17.2 \%)$ \\
Rhinobyon & $49(14.0 \%)$ \\
Comorbidity & \\
Hypertension & $45(12.9 \%)$ \\
Hyperlipidemia & $32(9.2 \%)$ \\
Thyroid disease & $31(8.9 \%)$ \\
Diabetes & $25(7.2 \%)$ \\
Heart disease & $12(3.4 \%)$ \\
Nephropathy & $6(1.7 \%)$ \\
Cancer & $4(1.1 \%)$ \\
Others & $44(12.6 \%)$ \\
None & $214(61.3 \%)$ \\
\hline
\end{tabular}

Table 2. Medication for COVID-19 patients $(n=349)$

\begin{tabular}{ll}
\hline Drug name & No. (\%) of patients $(\mathbf{n = 3 4 9 )}$ \\
\hline Lianhua Qingwen Granule & $324(92.8 \%)$ \\
Oseltamivir & $288(82.5 \%)$ \\
Arbidol & $247(70.8 \%)$ \\
Ribavirin & $17(4.9 \%)$ \\
Interferon & $6(1.7 \%)$ \\
Moxifloxacin & $255(73.1 \%)$ \\
Cefdinir & $128(36.7 \%)$ \\
Levofloxacin & $112(31.1 \%)$ \\
Amoxicillin & $22(6.3 \%)$ \\
Chinese medicine & $226(64.8 \%)$ \\
Cough Medicine & $31(8.29 \%)$ \\
Ibuprofen & $48(12.83 \%)$ \\
\hline
\end{tabular}


Table 3. Reported adverse drug reaction by COVID-19 patients $(n=349)$

\begin{tabular}{ll}
\hline Symptom & No. $(\%)$ of patients $(\mathbf{n}=\mathbf{3 4 9})$ \\
\hline Nausea & $74(21.2 \%)$ \\
Diarrhoea & $73(20.9 \%)$ \\
Fatigue & $70(20.1 \%)$ \\
Sleeplessness & $38(10.9 \%)$ \\
Skin pruritus & $33(9.5 \%)$ \\
Vomiting & $32(9.2 \%)$ \\
Constipation & $13(3.7 \%)$ \\
Dysuria & $13(3.7 \%)$ \\
Others & $19(5.4 \%)$ \\
None & $88(25.2 \%)$ \\
\hline
\end{tabular}

Table 4. Questions collected from COVID-19 patients

\begin{tabular}{ll}
\hline Question classification & No. (\%) of questions (n=196) \\
\hline COVID-19 related problems & $57(29.1 \%)$ \\
Initial symptoms, disease progression, sequelae, & $19(9.7 \%)$ \\
relapse & $20(10.2 \%)$ \\
complications & $18(9.2 \%)$ \\
Disease detection index & $82(41.8 \%)$ \\
COVID-19 medication related problems & $35(17.9 \%)$ \\
Drug selection problems and drug precautions & $16(8.2 \%)$ \\
Adverse drug reaction & $14(7.1 \%)$ \\
Treatment of asymptomatic infections & $11(5.6 \%)$ \\
Drug interaction problem & $24(12.2 \%)$ \\
Basic chronic illness related problems & $9(4.6 \%)$ \\
Diabetes related problems, such as medication & \\
reconciliation & $10(5.1 \%)$ \\
Cardiovascular and cerebrovascular diseases & \\
related problems & $5(2.5 \%)$ \\
Other chronic disease related problems & $15(7.7 \%)$ \\
Life related problems & $4(2.0 \%)$ \\
Diet and nutrition related problems & $2(1.0 \%)$ \\
Exercise at Fangcang hospital & $9(4.6 \%)$ \\
Others & $18(9.2 \%)$ \\
Matters of discharge & $11(9.2 \%)$ \\
Discharge related problems & $3(1.5 \%)$ \\
Medications out of hospital &
\end{tabular}

Table 5 Satisfaction of clinical pharmaceutical care for patients $(n=78)$ 


\begin{tabular}{|c|c|c|c|c|c|c|c|c|c|c|}
\hline $\begin{array}{l}\text { Survey } \\
\text { items }\end{array}$ & $\begin{array}{l}\text { Survey } \\
\text { items }\end{array}$ & $\begin{array}{l}\text { Survey } \\
\text { items }\end{array}$ & $\begin{array}{l}\text { Great } \\
\text { No.(\%) }\end{array}$ & $\begin{array}{l}\text { Great } \\
\text { No.(\%) }\end{array}$ & $\begin{array}{l}\text { Good } \\
\text { No. }(\%)\end{array}$ & $\begin{array}{l}\text { Good } \\
\text { No. }(\%)\end{array}$ & $\begin{array}{l}\text { Fair } \\
\text { No.(\%) }\end{array}$ & $\begin{array}{l}\text { Fair } \\
\text { No. }(\%)\end{array}$ & $\begin{array}{l}\text { Fair } \\
\text { No.(\%) }\end{array}$ & $\begin{array}{l}\text { Fair } \\
\text { No. }(\%)\end{array}$ \\
\hline $\begin{array}{l}\text { The } \\
\text { knowl- } \\
\text { edge- } \\
\text { ment } \\
\text { of } \\
\text { clini- } \\
\text { cal } \\
\text { phar- } \\
\text { ma- } \\
\text { cists } \\
\text { be- } \\
\text { fore } \\
\text { service }\end{array}$ & $\begin{array}{l}\text { The } \\
\text { knowl- } \\
\text { edge- } \\
\text { ment } \\
\text { of } \\
\text { clini- } \\
\text { cal } \\
\text { phar- } \\
\text { ma- } \\
\text { cists } \\
\text { be- } \\
\text { fore } \\
\text { service }\end{array}$ & $\begin{array}{l}\text { The } \\
\text { knowl- } \\
\text { edge- } \\
\text { ment } \\
\text { of } \\
\text { clini- } \\
\text { cal } \\
\text { phar- } \\
\text { ma- } \\
\text { cists } \\
\text { be- } \\
\text { fore } \\
\text { service }\end{array}$ & $6.4 \%$ & $6.4 \%$ & $5.1 \%$ & $5.1 \%$ & $14.1 \%$ & $14.1 \%$ & $14.1 \%$ & $14.1 \%$ \\
\hline $\begin{array}{l}\text { The } \\
\text { knowl- } \\
\text { edge- } \\
\text { ment } \\
\text { of } \\
\text { clini- } \\
\text { cal } \\
\text { phar- } \\
\text { ma- } \\
\text { cists } \\
\text { after } \\
\text { service }\end{array}$ & $\begin{array}{l}\text { The } \\
\text { knowl- } \\
\text { edge- } \\
\text { ment } \\
\text { of } \\
\text { clini- } \\
\text { cal } \\
\text { phar- } \\
\text { ma- } \\
\text { cists } \\
\text { after } \\
\text { service }\end{array}$ & $\begin{array}{l}\text { The } \\
\text { knowl- } \\
\text { edge- } \\
\text { ment } \\
\text { of } \\
\text { clini- } \\
\text { cal } \\
\text { phar- } \\
\text { ma- } \\
\text { cists } \\
\text { after } \\
\text { service }\end{array}$ & $9.0 \%$ & $9.0 \%$ & $35.9 \%$ & $35.9 \%$ & $42.3 \%$ & $42.3 \%$ & $42.3 \%$ & $42.3 \%$ \\
\hline $\begin{array}{l}\text { Patients' } \\
\text { recognition }\end{array}$ & $\begin{array}{l}\text { Patients' } \\
\text { recognition }\end{array}$ & $\begin{array}{l}\text { Patients' } \\
\text { recognition }\end{array}$ & $46.2 \%$ & $46.2 \%$ & $42.3 \%$ & $42.3 \%$ & $7.7 \%$ & $7.7 \%$ & $7.7 \%$ & $7.7 \%$ \\
\hline $\begin{array}{l}\text { Patients' } \\
\text { bene- } \\
\text { fit on } \\
\text { ratio- } \\
\text { nal } \\
\text { drug } \\
\text { use }\end{array}$ & $\begin{array}{l}\text { Patients' } \\
\text { bene- } \\
\text { fit on } \\
\text { ratio- } \\
\text { nal } \\
\text { drug } \\
\text { use }\end{array}$ & $\begin{array}{l}\text { Patients' } \\
\text { bene- } \\
\text { fit on } \\
\text { ratio- } \\
\text { nal } \\
\text { drug } \\
\text { use }\end{array}$ & $38.5 \%$ & $38.5 \%$ & $52.6 \%$ & $52.6 \%$ & 0 & 0 & 0 & 0 \\
\hline $\begin{array}{l}\text { Satisficatio } \\
\text { with } \\
\text { this } \\
\text { service }\end{array}$ & $\begin{array}{l}\text { Satisficatio } \\
\text { with } \\
\text { this } \\
\text { service }\end{array}$ & $\begin{array}{l}\text { Satisficatio } \\
\text { with } \\
\text { this } \\
\text { service }\end{array}$ & $166.7 \%$ & $66.7 \%$ & $18.0 \%$ & $18.0 \%$ & $14.1 \%$ & $14.1 \%$ & $14.1 \%$ & $14.1 \%$ \\
\hline $\begin{array}{l}\text { Necessary } \\
\text { of this } \\
\text { service }\end{array}$ & $\begin{array}{l}\text { Necessary } \\
\text { of this } \\
\text { service }\end{array}$ & $\begin{array}{l}\text { Necessary } \\
\text { of this } \\
\text { service }\end{array}$ & $62.8 \%$ & $62.8 \%$ & $32.1 \%$ & $32.1 \%$ & $5.1 \%$ & $5.1 \%$ & $5.1 \%$ & $5.1 \%$ \\
\hline $\begin{array}{l}\text { Benefit } \\
\text { on } \\
\text { psy- } \\
\text { cho- } \\
\text { logical } \\
\text { help }\end{array}$ & $\begin{array}{l}\text { Benefit } \\
\text { on } \\
\text { psy- } \\
\text { cho- } \\
\text { logical } \\
\text { help }\end{array}$ & $\begin{array}{l}\text { Benefit } \\
\text { on } \\
\text { psy- } \\
\text { cho- } \\
\text { logical } \\
\text { help }\end{array}$ & $16.7 \%$ & $16.7 \%$ & $43.6 \%$ & $43.6 \%$ & $26.9 \%$ & $26.9 \%$ & $26.9 \%$ & $26.9 \%$ \\
\hline
\end{tabular}




\begin{tabular}{|c|c|c|c|c|c|c|c|c|c|c|}
\hline $\begin{array}{l}\text { Survey } \\
\text { items }\end{array}$ & $\begin{array}{l}\text { Survey } \\
\text { items }\end{array}$ & $\begin{array}{l}\text { Survey } \\
\text { items }\end{array}$ & $\begin{array}{l}\text { Great } \\
\text { No. }(\%)\end{array}$ & $\begin{array}{l}\text { Great } \\
\text { No. }(\%)\end{array}$ & $\begin{array}{l}\text { Good } \\
\text { No. }(\%)\end{array}$ & $\begin{array}{l}\text { Good } \\
\text { No. }(\%)\end{array}$ & $\begin{array}{l}\text { Fair } \\
\text { No. }(\%)\end{array}$ & $\begin{array}{l}\text { Fair } \\
\text { No. }(\%)\end{array}$ & $\begin{array}{l}\text { Fair } \\
\text { No. }(\%)\end{array}$ & $\begin{array}{l}\text { Fair } \\
\text { No. }(\%)\end{array}$ \\
\hline $\begin{array}{l}\text { Usefulness } \\
\text { of } \\
\text { phar- } \\
\text { ma- } \\
\text { ceuti- } \\
\text { cal } \\
\text { care } \\
\text { for } \\
\text { out- } \\
\text { come } \\
\text { of } \\
\text { disease }\end{array}$ & $\begin{array}{l}\text { Usefulness } \\
\text { of } \\
\text { phar- } \\
\text { ma- } \\
\text { ceuti- } \\
\text { cal } \\
\text { care } \\
\text { for } \\
\text { out- } \\
\text { come } \\
\text { of } \\
\text { disease }\end{array}$ & $\begin{array}{l}\text { Usefulness } \\
\text { of } \\
\text { phar- } \\
\text { ma- } \\
\text { ceuti- } \\
\text { cal } \\
\text { care } \\
\text { for } \\
\text { out- } \\
\text { come } \\
\text { of } \\
\text { disease }\end{array}$ & $21.8 \%$ & $21.8 \%$ & $43.6 \%$ & $43.6 \%$ & $33.3 \%$ & $33.3 \%$ & $33.3 \%$ & $33.3 \%$ \\
\hline $\begin{array}{l}\text { Frequency } \\
\text { of } \\
\text { service }\end{array}$ & $\begin{array}{l}\text { Frequency } \\
\text { of } \\
\text { service }\end{array}$ & $\begin{array}{l}\text { Once a } \\
\text { day } \\
(48.7 \%)\end{array}$ & $\begin{array}{l}\text { Once } \\
\text { per } 2 \\
\text { days } \\
(20.5 \%)\end{array}$ & $\begin{array}{l}\text { Once } \\
\text { per } 2 \\
\text { days } \\
(20.5 \%)\end{array}$ & $\begin{array}{l}\text { Once } \\
\text { per } 2 \\
\text { days } \\
(20.5 \%)\end{array}$ & $\begin{array}{l}\text { Once } \\
\text { per } 3 \\
\text { days } \\
(7.7 \%)\end{array}$ & $\begin{array}{l}\text { Once } \\
\text { per } 3 \\
\text { days } \\
(7.7 \%)\end{array}$ & $\begin{array}{l}\text { Once } \\
\text { per } 3 \\
\text { days } \\
(7.7 \%)\end{array}$ & $\begin{array}{l}\text { Once } \\
\text { per } 3 \\
\text { days } \\
(7.7 \%)\end{array}$ & $\begin{array}{l}\text { Once a } \\
\text { week } \\
(14.1 \%)\end{array}$ \\
\hline \multirow[t]{2}{*}{$\begin{array}{l}\text { Pharmace } \\
\text { care } \\
\text { services }\end{array}$} & $\begin{array}{l}\text { dosipang } \\
\text { dosage } \\
(65.4 \%)\end{array}$ & $\begin{array}{l}\text { Drug } \\
\text { dosage } \\
(65.4 \%)\end{array}$ & $\begin{array}{l}\text { Drug } \\
\text { dosage } \\
(65.4 \%)\end{array}$ & $\begin{array}{l}\text { Medication } \\
\text { reconcil- } \\
\text { iation } \\
(55.1 \%)\end{array}$ & $\begin{array}{l}\text { Medication } \\
\text { reconcil- } \\
\text { iation } \\
(55.1 \%)\end{array}$ & $\begin{array}{l}\text { Medication } \\
\text { reconcil- } \\
\text { iation } \\
(55.1 \%)\end{array}$ & $\begin{array}{l}\text { Medication } \\
\text { reconcil- } \\
\text { iation } \\
(55.1 \%)\end{array}$ & $\begin{array}{l}\text { Contrain } \\
(23.1 \%)\end{array}$ & $\begin{array}{l}\text { idationtrising } \\
(23.1 \%)\end{array}$ & $\begin{array}{l}\text { idatinotrsind } \\
(23.1 \%)\end{array}$ \\
\hline & $\begin{array}{l}\text { Adverse } \\
\text { drug } \\
\text { reaction } \\
(35.9 \%)\end{array}$ & $\begin{array}{l}\text { Adverse } \\
\text { drug } \\
\text { reaction } \\
(35.9 \%)\end{array}$ & $\begin{array}{l}\text { Adverse } \\
\text { drug } \\
\text { reaction } \\
(35.9 \%)\end{array}$ & \multicolumn{6}{|c|}{ 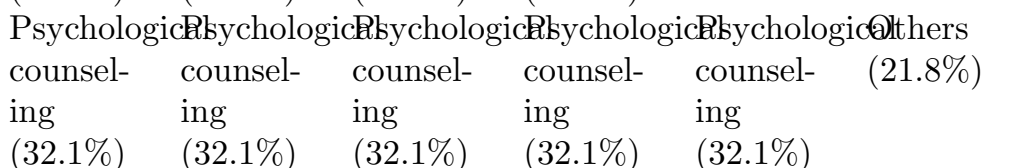 } & $\begin{array}{l}\text { Others } \\
(21.8 \%)\end{array}$ \\
\hline
\end{tabular}

